\title{
RELATION OF SEVERAL PEDOLOGICAL CHARACTERISTICS TO ENGINEERING QUALITIES OF SOIL
}

\author{
D. DE LA ROSA \\ (Centro de Edafología y Biología Aplicada del Cuarto, \\ C.S.I.C., Apartado 1052, Sevilla, Spain)
}

\begin{abstract}
Summary
An attempt to predict engineering qualities which are needed in soil evaluation and to enhance nonagricultural use of soil survey data was made. Data from a variety of soils were subjected to simple correlation and multiple regression analyses to relate three pedologic characteristics: clay content, cation-xchange capacity (CEC), and organic matter content to two engineering qualitites: plasticity index, and optimum moisture. Simple correlation coefficients showed that clay content and CEC correlated significantly with the engineering determinations. The relationship between organic matter content and these engineering determinations was weaker. Multiple regression analyses showed that the three pedologic characteristics accounted for most of the variation in each of the engineering qualities, and that prediction was feasible.
\end{abstract}

\section{Introduction}

THE non-agricultural use of soil survey data is continually increasing. However, the soil qualities which are diagnostic criteria in engineering evaluation are not usually provided by soil survey. In the systems most commonly used for engineering purposes, such as the Unified Soil Classification System developed by the United States Department of Defense (1968) and the American Association of State Highway Officials Classification System (AASHO, 1961), the soils are classified according to plasticity, compaction, and water status.

The range of water content over which a soil exhibits plastic behaviour is defined as that between the lower plastic limit and the upper plastic limit or liquid limit. These measurements of plasticity are based on the work of Atterberg and are sometimes called Atterberg limits. Plasticity index is defined as liquid limit minus plastic limit (Yong and Warkentin, 1966). The density to which a given soil can be compacted varies with water content and force of compaction. Compactive test, sometimes called the Proctor test, was developed to establish the relationship between density of a soil, water content, and force of compaction. If a soil material is compacted at successively higher moisture content, assuming that the compactive effort remains constant, the soil density increases until the optimum moisture content is reached. After that, density decreases with increase in moisture content (Felt, 1950).

In the work reported here, an at tempt was made to predict engineering qualities by studying the relationship between these determinations and other pedologic characteristics provided by agricultural soil survey. This paper relates clay content, $\mathrm{CEC}$, and organic matter content with plasticity index, and optimum moisture of a range of Florida soils. Correlation and multiple regression analyses were employed to investigate these relationships. 


\section{Materials and Methods}

Fifty-four soil samples from subsurface horizons representing 38 soil series were used. They represent a broad spectrum of Florida soils which were characterized as part of the Florida Soil Survey Program and research activities of the Florida Agricultural Experiment Stations during the past 15 years (Calhoun et al., 1974). These soils were classified in 4 soil orders: alfisols, entisols, spodosols, and ultisols, as defined by Soil Survey Staff (1975).

Clay content was determined by the hydrometer method (Bouyoucos, 1962). CEC was measured by $\mathrm{NH}_{4}^{+}$saturation, displacement, and titration of $\mathrm{NH}_{3}$ collected in boric acid. Organic matter content was determined by multiplying percent organic $\mathrm{C}$ by the conversion factor 1.72 . Organic $\mathrm{C}$ was measured by the acid dichromate digestion method No. 6Ala (Soil Survey Staff, 1972). Plastic limit and liquid limit were determined by methods Nos. D423 and D424 (American Society for Testing and Materials, 1970), respectively. Optimum moisture content was based on AASHO designation T99-57, method A (American Association of State Highway Officials, 1961).

The predicted engineering qualities of soil were related to the pedologic characteristics by functions of the type

$$
Y=\phi\left(x_{1}, x_{2}, x_{3}\right)+\epsilon
$$

where $\epsilon$ measures the experimental error. As the mathematical form of $\phi$ is not known, the functions can be approximated satisfactorily, within the experimental region, by polynomials of the variables $x_{n}$ (Cochran and Cox, 1962). Thus the following polynomial type was used

$Y=b_{0}+b_{1} X_{1}+b_{2} X_{2}+b_{3} X_{3}+b_{12} X_{1} X_{2}+b_{13} X_{1} X_{3}+b_{23} X_{2} X_{3}+b_{123} X_{1} X_{2} X_{3}$ where $Y$ represents the predicted plasticity index $\left(Y_{1}\right)$, and optimum moisture $\left(Y_{2}\right)$; and $b_{1}, b_{2}, \ldots$ are the partial regression coefficients for the independent variables clay content $\left(X_{1}\right), \operatorname{CEC}\left(X_{2}\right)$, and organic matter content $\left(X_{3}\right)$, and their interactions of second and third order.

The calibation of these polynomial equations was treated statistically as a particular case of multiple regression. Correlation and stepwise multiple regression analyses were performed using the Statistical Analysis System (Barr et al., 1976) on an Amdahl 470 V/6-11 computer at the Northeast Regional Center, Gainesville, Florida.

\section{Results and Discussion}

The clay content, CEC, organic matter content, plasticity index, and optimum moisture data for the 54 soil samples investigated are summarized in Table 1. The soils contained considerable amounts of clay and had moderately low CEC. This appears to be due to the type of clay mineral present, which is mainly kaolinite. However, the organic matter contents were low with an average of only 0.5 per cent.

In considering the statistical analyses it has been noted that, multiple regression equations are notoriously untrustworthy when extrapolated. Also, a polynomial equation can be regarded only as an approximation to $\phi$ within the experimental region covered by the study (Table 1). Thus, predictions refer to sites similar to those where measurements were made.

Simple correlations between the paired soil characteristics were calculated and are shown in Table 2 . All correlations between clay content and plasticity index, and 
TABLE 1

Range and mean for selected properties in the soils investigated

\begin{tabular}{lcr}
\hline Soil property & Range & Mean \\
\hline Clay content, $\%$ & $0.1-93.5$ & 25.6 \\
Cation-exchange capacity, meq/100 g & $0.2-34.9$ & 7.2 \\
Organic matter content, $\%$ & $0.1-4.5$ & 0.5 \\
Plasticity index & $1.0^{*}-116.0$ & 16.6 \\
Optimum moisture, $\%$ & $10.2-45.6$ & 17.8 \\
\hline
\end{tabular}

$* 1.0 \cong$ Nonplastic.

optimum moisture proved to be highly significant ( 0.1 per cent level). CEC was also significantly correlated ( 0.1 per cent level) with the engineering determinations. However, the correlation coefficients for organic matter with plasticity index, and optimum moisture were very low in absolute value. The correlation matrix (Table 2) provided a convenient starting point in estimating the contribution of $X$-variables to the engineering qualities, as well as the possible second order interactions between $X$-variables.

Multiple regression equations of the data obtained with the soil samples investigated are given in Table 3 . In the stepwise multiple regression analysis, the equations were selected taking in to account the main effects of the $X$-variables considered and major interactions of second and third order, along with their capacity of abstraction and simplicity. The regression equations were forced through the origin because $R^{2}$-values were rather low when the intercept term was included in the models.

For the plasticity index $\left(Y_{1}\right)$, the coefficient of multiple determination $\left(R^{2}\right.$. value) shows that this equation accounted for 97 per cent of the observed variation. The coefficient of variation of the predicted variable is moderately low (c.v. = 26.45 per cent), indicating that the probability of error in applying this equation for predicting plasticity index is low (Table 3 ). The significance of the numerical coefficients ( $b$-values) was also tested. The $t$-value for clay content $\left(t_{1}\right)$ is highly significant ( 0.1 per cent level); however, for $\operatorname{CEC}\left(t_{2}\right)$ it is not significant. The $t_{3}$ and $t_{4}$ for clay content-CEC and clay content-CEC-organic matter content interactions, respectively, are also highly significant $(0.1$ per cent level $)$, although these values are lower than for $t_{1}$.

TABLE 2

Simple correlation coefficients between selected soil properties

\begin{tabular}{|c|c|c|c|c|c|}
\hline & \multicolumn{5}{|c|}{ Simple correlation coefficient $(r)$} \\
\hline & Clay & $C E C^{*}$ & $O M^{*}$ & $P I^{*}$ & $O H^{*}$ \\
\hline $\begin{array}{l}\text { Clay } \\
\text { CEC* } \\
\mathrm{OM}^{*} \\
\mathrm{PI}^{*} \\
\mathrm{OH}^{*}\end{array}$ & & $0.62 \ddagger$ & $\begin{array}{c}-0.31 \dagger \\
0.04\end{array}$ & $\begin{array}{r}0.91 \ddagger \\
0.73 \ddagger \\
-0.25\end{array}$ & $\begin{array}{c}0.71 \ddagger \\
0.62 \ddagger \\
-0.13 \\
0.77 \ddagger\end{array}$ \\
\hline
\end{tabular}

${ }^{*} \mathrm{CEC}, \mathrm{OM}, \mathrm{PI}$, and $\mathrm{OH}$ represent cation-exchange capacity, organic matter content, plasticity index, and optimum moisture, respectively.

$\dagger, \ddagger$ Statistically significant at $5 \%$ and $0.1 \%$ levels, respectively. 
For optimum moisture $\left(Y_{2}\right)$, the $R^{2}$-value shows that the equation reported in Table 3 accounted for 85 per cent of the observed variation. The coefficient of variation of the predicted variable is moderately high (c.v. $=43.35$ per cent). The test of significance for partial regression coefficients shows that the $t$-values for clay content $\left(t_{1}\right)$, and CEC $\left(t_{2}\right)$ are highly significant $\left(0.1\right.$ per cent level). The $t_{3}$ and $t_{4}$ for clay content-CEC and clay content-CEC-organic matter content in teractions, respectively, are not significant; both values being much lower than for $t_{1}$.

Although simple correlation analyses showed that organic matter content was not significantly correlated with plasticity index and optimum moisture (Table 2), multiple regression analyses showed that organic matter content had important effects (its interactions with CEC or with clay content and CEC, but not its main effects) on these engineering determinations of the soils studied.

The most appropriate models for plasticity index and optimum moisture (Table 3), were converted to two $X$-variables equations, by making organic matter $\left(X_{3}\right)$ equal to the average content $(0.5$ per cent) of the soils investigated. These three-dimensional surfaces were examined by plotting equal response contours (Fig. 1, and 2). These graphs could be used to predict approximately the engineering qualities of soil from clay content and CEC.

It may be concluded that polynomial equations solved by numerical computation methods can be used to predict engineering qualities of soil. Multiple regression analysis indicated that the clay content, CEC, organic matter, and their interactions accounted for most of the variation in plasticity index, and optimum moisture. Although the prediction interval was moderately large for optimum moisture.

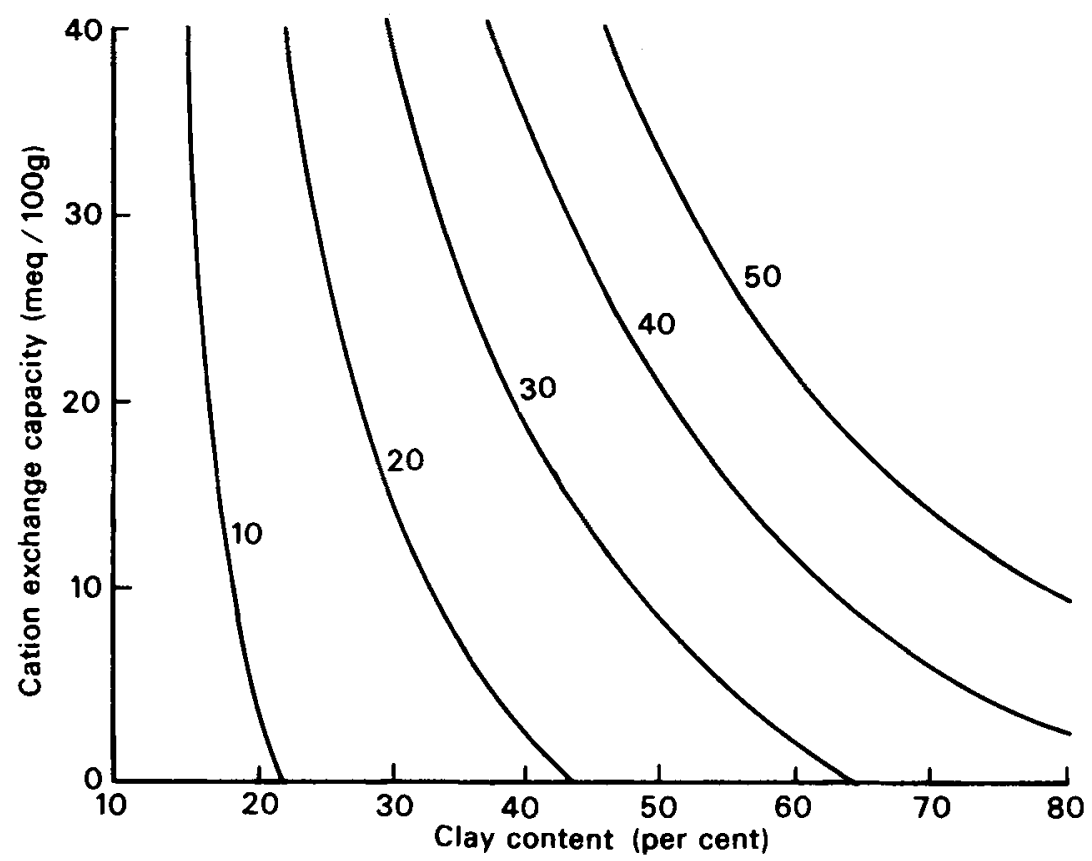

FIG. 1. Equal response contours of the three-dimensional surface for plasticity index. 


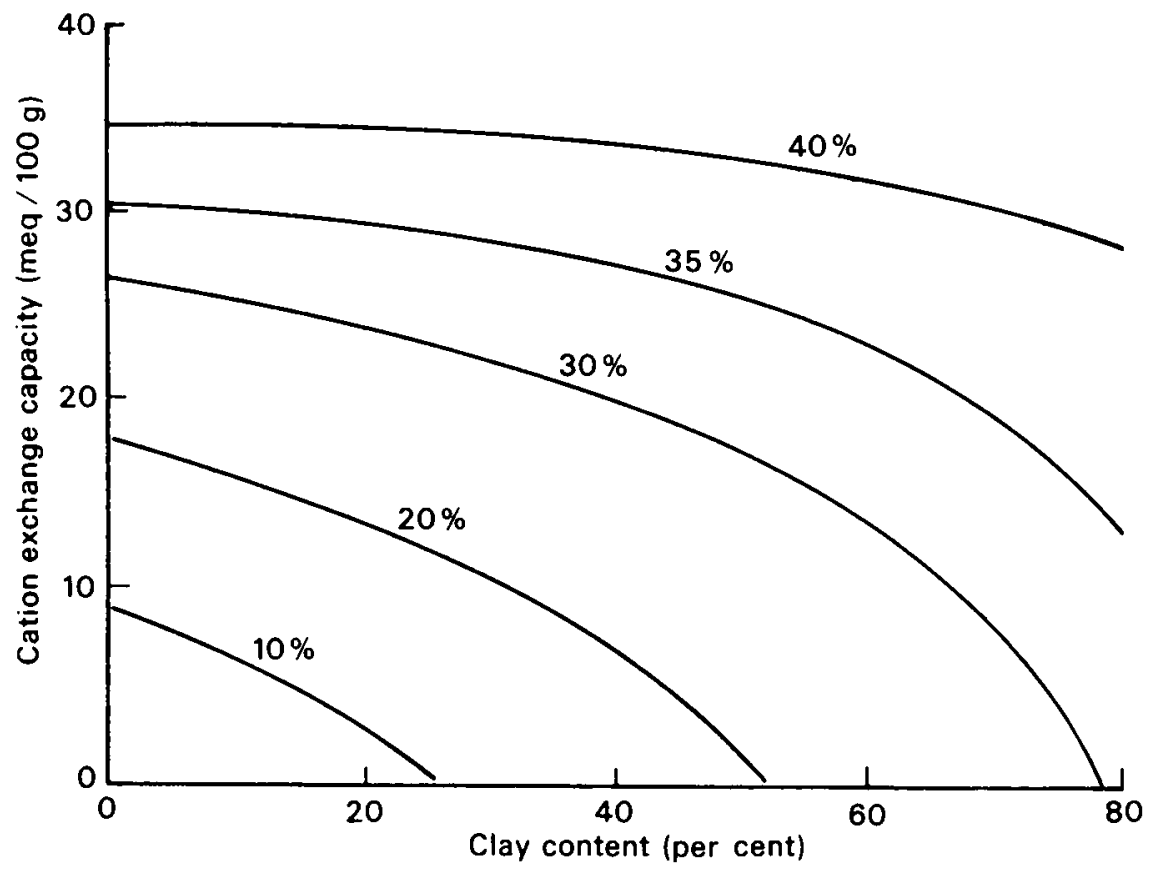

FIG. 2. Equal response contours of the three-dimensional surface for optimum moisture.

\section{Acknowledgements}

This work was supported in part by the Program of Cultural Cooperation between the United States of America and Spain, administered by the Fulbright Commission. The author gratefully acknowledges the fellowship conceded by the Soil Science Department, University of Florida.

\section{REFERENCES}

AMERICAN ASSOCIATION OF STATE HIGHWAY OFFICIALS. 1961. Standard specifications for high way materials and methods of sampling and testing. Ed. 8, 2v.

AMERICAN SOCIETY FOR TESTING AND MATERIALS. 1970. Book of ASTM standards, pp. 212-219.

BARR, A. J., GOODNIGHT, J. H., SALL, J. P., and HELWIG, J. T. 1976. SAS 76. Statistical analysis systems. SAS Inst. Raleigh, N.C. (USA).

BOUYOUCOS, G. J. 1962 . Hydrometer method improved for making particle size analyses of soils. Agron. 54, 464-5.

CALHOUN, F. G., CARLiSle, V. W., CALDWEll, R. E., ZELAZNY, L. W., HAMMOND, L. C., and BRELAND, H. L. 1974. Characterization data for selected Florida soils. Univ. of Florida. Soil Sci. Dept. Rep. No. 74-1. Gainesville, Fla. (USA).

COCHRAN, W. G., and COX, G. M. 1962. Experimental designs. J. Wiley and Sons, Inc. Pub. New York, N.Y. (USA).

FELT, E. J. 1950. Soil series name as a basis for interpretative soil classification for engineering purposes. Am. Soc. Test. Mat. Spec. Pub. No. 113: 62-79.

SOIL SURVEY STAFF. 1972. Soil survey laboratory methods and procedures for collecting soil samples. Soil Conservation Service, USDA Soil Surv. Inv. Rep. No. 1, U.S. Govt. Printing Office, Washington, D.C. (USA). 
SOIL SURVEY STAFF. 1975. Soil taxonomy; $A$ basic system of soil classification for making and interpreting soil surveys. Soil Conservation Service, USDA Handbook No. 436, U.S. Govt. Printing Office, Washington, D.C. (USA).

U.S. DEPARTMENT OF DEFENSE. 1968. Unified soil classification system for roads, airfields, embankments, and foundations. MILSTD-619B.

YONG, R. N., and WARKENTIN, B. P. 1966. Introduction to soil behavior. MacM. Co., New York, N.Y. (USA).

(Received 3 July 1978) 